\title{
The major pathway by which polymeric formula reduces inflammation in intestinal epithelial cells: a microarray-based analysis
}

\author{
Lily Nahidi $^{1}$ - Susan M. Corley ${ }^{2} \cdot$ Marc R. Wilkins $^{2} \cdot$ Jerry Wei $^{3}$. \\ Moftah Alhagamhmad ${ }^{1}$ Andrew S. Day ${ }^{1,4,5}$ - Daniel A. Lemberg ${ }^{1,6}$. \\ Steven T. Leach ${ }^{1}$ (1)
}

Received: 16 April 2015/Accepted: 2 July 2015/Published online: 17 July 2015

(C) Springer-Verlag Berlin Heidelberg 2015

\begin{abstract}
Nutritional therapy is well established as a means to induce remission in active Crohn's disease (CD). Evidence indicates that exclusive enteral nutrition (EEN) therapy for $\mathrm{CD}$ both alters the intestinal microbiota and directly suppresses the inflammatory response in the intestinal mucosa. However, the pathway(s) through which EEN suppresses inflammation is still unknown. Therefore, the aim of the current study was to use microarray technology to investigate the major pathway by which polymeric formula (PF) alters inflammatory processes in epithelial cells in vitro. HT-29 cells were grown to confluence and then co-cultured with tumour necrosis factor (TNF)- $\alpha(100 \mathrm{ng} / \mathrm{ml})$ for $5 \mathrm{~h}$ in the presence or absence of $\mathrm{PF}$, as used for EEN. Following incubation, RNA was
\end{abstract}

Electronic supplementary material The online version of this article (doi:10.1007/s12263-015-0479-x) contains supplementary material, which is available to authorized users.

Steven T. Leach

s.leach@unsw.edu.au

1 School of Women's and Children's Health, Westfield Research Laboratories, Level 2, Sydney Children's Hospital, University of New South Wales, High Street, Randwick, Sydney, NSW 2031, Australia

2 Systems Biology Initiative, School of Biotechnology and Biomolecular Sciences, University of New South Wales, Sydney, NSW, Australia

3 Sydney Medical School, University of Sydney, Sydney, NSW, Australia

4 Paediatric Gastroenterology, Christchurch Hospital, Christchurch, New Zealand

5 Department of Paediatrics, University of Otago, Christchurch, New Zealand

6 Department of Gastroenterology, Sydney Children's Hospital, Randwick, Sydney, NSW, Australia extracted and subjected to polymerase chain reaction (PCR) and microarray analysis. Enzyme-linked immunosorbent assays were employed to evaluate cytokine protein levels. Neither TNF- $\alpha$ nor PF had a toxic effect on cells over the experimental period. Microarray analysis showed that PF modulated the expression of genes specifically linked to nuclear factor (NF)- $\mathrm{\kappa B}$, resulting in downregulation of a number of genes in this pathway. These findings were further confirmed by real-time PCR of selected dysregulated genes as well as reduced expression of IL-6 and IL-8 proteins following PF treatment. The results arising from this study provide evidence that $\mathrm{PF}$ alters the inflammatory responses in intestinal epithelial cells through modulation of the NF-кB pathway.

Keywords Crohn's disease $\cdot$ NF- $\kappa B$ - Polymeric formula $\cdot$ EEN $\cdot$ Microarray

\section{Introduction}

Crohn's disease (CD) is one of the inflammatory bowel diseases (IBDs) and is a lifelong, debilitating disease of unknown aetiology (Griffiths and Buller 2000). CD can impact upon the nutritional state of patients (Griffiths and Buller 2000) and is usually diagnosed during young adulthood; however, an increasing incidence has been reported in the paediatric age group throughout the world (Benchimol et al. 2011). Both children and adolescents presenting with $\mathrm{CD}$ commonly suffer from under-nutrition and weight loss during different stages of their disease (Day et al. 2008). In paediatric CD, nutritional impairment further complicates the disease and can lead to delayed pubertal development (Ballinger et al. 2003), impaired linear growth (Kanof et al. 1988) and lower bone mineral 
density (Robinson et al. 1998). Given the adverse nutritional impacts of $\mathrm{CD}$ in both children and adolescents, appropriate attention to the nutritional status of these individuals is now a central consideration in the management of their disease (Day and Burgess 2013; Day et al. 2006, 2008).

Nutritional therapy has been shown to be a valid therapeutic option for induction and maintenance of remission along with correction of nutritional deficits, and re-establishment of growth in both adults and children with CD (Otley et al. 2010). The value of nutritional therapy centres upon the use of exclusive enteral nutrition (EEN) to manage patients with active CD. EEN involves the provision of a liquid formula given exclusively with cessation of normal diet for a period of up to 12 weeks (Day and Burgess 2013). The liquid formula may contain intact proteins (polymeric) or modified proteins and individual amino acids (semi-elemental or elemental) (Ludvigsson et al. 2004). Studies have shown that polymeric formula (PF) has equivalent efficacy to elemental formula although $\mathrm{PF}$ is superior in terms of acceptance and tolerability (Ludvigsson et al. 2004). In addition, there are data that EEN improves the patient's nutritional status (Thomas et al. 1993). Beyond the nutritional benefits, EEN has been shown to alleviate clinical symptoms and rapidly decrease disease activity in $\mathrm{CD}$ patients by influencing the underlying mucosal immune response and inflammatory processes (de Jong et al. 2007; Fell et al. 2000). Furthermore, EEN is considered safe, as it induces remission and mucosal healing with minimal side effects compared to current pharmacological therapies (Fell et al. 2000). However, the pathway(s) by which EEN alters events in the gut epithelium and exerts its clinical benefits, independent of modulation of intestinal bacteria, is still unknown.

The aim of the current study was to use microarray technology to investigate the pathway(s) by which PF alters epithelial inflammatory processes in an established in vitro model of gut inflammation.

\section{Materials and methods}

\section{Materials and reagents}

Recombinant human tumour necrosis factor (TNF)- $\alpha$ and basic chemicals were purchased from Sigma (St. Louis, MO, USA). Commercial human interleukin (IL)-6 enzymelinked immunosorbent assay (ELISA) kit was obtained from Biosource International (Camarillo, CA, USA). Polymerase chain reaction (PCR) primers and IL-8 ELISA kit were from Invitrogen (Carlsbad, CA, USA). Human colonic epithelial cells [HT-29 (ATCC HTB-38)] were from the American Type Culture Collection (ATCC). All cell culture reagents were obtained from Gibco Invitrogen (Carlsbad, CA, USA). The PF used in this study was Osmolite (C) 1 Cal (Abbott Nutrition, NSW, Australia) with osmolality $300 \mathrm{mOsm} / \mathrm{kg}$ and $\mathrm{pH}$ 6.6.

\section{Cell line and culture conditions}

HT-29 cells were cultured in McCoy's 5A (Gibco) medium supplemented with $10 \%$ heat-inactivated foetal bovine serum (FBS; Gibco) and $100 \mathrm{U} / \mathrm{ml}$ streptomycin and penicillin (Gibco) with $\mathrm{pH}$ of 7.2 and osmolality of $290 \mathrm{mOsm} / \mathrm{kg}$ (Otsuka et al. 1987). Cultures were maintained at $37{ }^{\circ} \mathrm{C}$ in $5 \% \mathrm{CO}_{2}$ in air within a humidified incubator, with media replenished every 1-2 days.

For experimentation, HT-29 cells were seeded in sixwell plates (Becton-Dickinson Biosciences, Bedford, MA, USA) and cultured for approximately 2 weeks until 80-90\% confluent. Prior to experiments, cells were washed twice with warm sterile $1 \times$ Dulbecco's phosphatebuffered saline (PBS; Gibco) and then treated with $100 \mathrm{ng} /$ $\mathrm{ml}$ of TNF- $\alpha$ in the presence or absence of PF (1:5 dilution) for $5 \mathrm{~h}$ (Boonkaewwan et al. 2008; de Jong et al. 2007). In each series of experiments, supernatants were collected following stimulation of the cells and stored at $-80{ }^{\circ} \mathrm{C}$ until required for subsequent analysis.

\section{Cell viability assays by the trypan blue exclusion method}

Experiments were carried out to evaluate the possible toxic effects of TNF- $\alpha$ and PF on cell viability. HT-29 cells were washed with warm $1 \times$ PBS and were detached with $0.25 \%$ trypsin/EDTA solution as described previously (de Jong et al. 2007; Nahidi et al. 2012). Warm FBS (500 $\mu \mathrm{l} /$ well) was added to inhibit the trypsin reaction. Cell suspensions were then mixed with an equal volume of trypan blue solution and applied to a haemocytometer chamber for cell counting (de Jong et al. 2007). Cells were examined by light microscope (Nikon, Japan) to detect any changes in morphology and to determine uptake of the dye (the trypan blue-negative cells were considered to be viable). Means were calculated from six independent cell counts and were used for analysis.

\section{RNA extraction and amplification by real-time PCR (RT-PCR)}

RNA was isolated from HT-29 cells with TRIzol total RNA isolation reagent (Invitrogen) as previously described (Nahidi et al. 2012, 2013). Isolated RNA was then subjected to DNAse treatment (Turbo DNA-free kit; Ambion, Austin, TX, USA) according to the manufacturer's instructions to remove any genomic DNA contamination 
(Nahidi et al. 2012, 2013). The quantity and quality of extracted RNA were evaluated by absorbance at 260:280 nm using a NanoDrop ND-1000 spectrophotometer (NanoDrop Technologies $\subset$, Wilmington, DE, USA). Thereafter, extracted RNA was reverse-transcribed into complementary DNAs (cDNA) using the superscript III reverse transcriptase enzyme (Invitrogen) following the manufacturer's protocol as previously described (Nahidi et al. 2012, 2013).

The RT-PCRs were performed using the Realplex Mastercycler (Eppendorf, Barkhausenweg, Hamburg, Germany) and SYBR Green (Bio-Rad) fluorescence sequence detection system as previously described (Nahidi et al. 2012, 2013). The final volume of each RT-PCR was $25 \mu \mathrm{l}$ consisting of $12.5 \mu \mathrm{l}$ of $\mathrm{iQ}^{\mathrm{TM}}$ SYBR Green PCR master mix, $5 \mu$ l of obtained cDNA ( $2 \mathrm{ng} / \mu \mathrm{l}$; or water as a negative control), nuclear-free water (Ambion), as well as sense and anti-sense primers designed specifically for quantitative RT-PCR and having similar efficiencies (Bahrami et al. 2011; Capasso et al. 2012; Nahidi et al. 2012; Watanabe et al. 2013; Zhang et al. 2009) (Table 1). Cycling temperatures for the RT-PCRs were as follows: initial hot start step of $2 \mathrm{~min}$ at $95{ }^{\circ} \mathrm{C}$ for all reactions, and then 40 cycles of $95{ }^{\circ} \mathrm{C}$ for $20 \mathrm{~s}, 63^{\circ} \mathrm{C}$ for $30 \mathrm{~s}$ and $72{ }^{\circ} \mathrm{C}$ for $60 \mathrm{~s}$. To ensure the specificity of amplification, each cycling programme was followed by a melting phase, and each melting curve was checked for the presence of a single peak to demonstrate a single amplification product. For each specimen, RT-PCRs were carried out in triplicate and the average threshold cycle $\left(C_{\mathrm{t}}\right)$ was calculated. All data are presented as mean $\Delta C_{\mathrm{t}}$ to $\beta_{2}$-microglobulin $\left(\beta_{2} \mathrm{M}\right.$; housekeeping gene; Table 1).

\section{Microarray experiments and analysis}

The pure extracted RNAs (500 ng; from untreated cells, cells exposed to TNF- $\alpha$ and cells exposed to TNF- $\alpha$ and
PF) with the 260:280 and 260:230 ratios between 1.8 and 2.3 were used for microarray analysis. Each sample was additionally run on the Agilent Bioanalyzer RNA Nano 6000 chip to further assess the quality and integrity of the total extracted RNA. We thus confirmed that all samples had an RNA integrity number (RIN) $>7$, before proceeding with microarray analysis. The samples were then subjected to Affymetrix microarray analysis with an Affymetrix Human PrimeView $^{\mathrm{TM}}$ (U219) GeneChip ${ }^{\circledR}$ according to the manufacturer's guidance (Santa Clara, CA, USA) performed at Ramaciotti Centre for Genomics. After scanning, array images were assessed by eye to confirm scanner alignment and the absence of significant bubbles or scratches on the chip surface. The protocols used for RNA microarray analysis were those available from Ramaciotti Centre for Genomics (http://www.ramaciotti.unsw.edu.au). The microarray data have been deposited in NCBI's Gene Expression Omnibus (GEO) and are accessible through GEO series accession number GSE69605.

\section{ELISA assays for IL-8 and IL-6}

The concentrations of IL- 8 and IL- 6 in culture supernatants were determined using a sandwich ELISA according to the manufacturer's specifications. In brief, collected supernatants and recombinant standards were added in duplicate into the 96-well plates (Maxisorp Nunc, Roskilde, Denmark), coated overnight at room temperature with primary antibodies and then detected by biotinylated secondary antibodies conjugated with horseradish peroxidase (HRP). After incubation for $2 \mathrm{~h}$, plates were thoroughly washed with $0.05 \%$ Tween 20 in PBS. Colour was developed by adding TMB substrate (Pierce Chemical, Rockford, IL, USA), and the reaction stopped after 3-5 min with the addition of $2 \mathrm{M} \mathrm{HCl}$. Absorbance was read at a wavelength of $450 \mathrm{~nm}$ using a microplate reader (Bio-Rad, Hercules, CA, USA). The levels were expressed as $\mathrm{pg} / \mathrm{ml}$ protein.

Table 1 Sequences of primers used for RT-PCR analysis

\begin{tabular}{|c|c|c|c|}
\hline Primer & Orientation & Sequence $\left(5^{\prime}-3^{\prime}\right)$ & References \\
\hline \multirow[t]{2}{*}{ IL-8 } & Sense & CCGGAAGGAACCATCTCACT & \multirow[t]{2}{*}{ Zhang et al. (2009) } \\
\hline & Anti-sense & ААСТТСТССАСААСССТСТGC & \\
\hline \multirow[t]{2}{*}{ NFKBIE } & Sense & GCATCTCATCCACTCTGTGCAA & \multirow[t]{2}{*}{ Watanabe et al. (2013) } \\
\hline & Anti-sense & CTGCCTGGCTTCAGTCGGTA & \\
\hline \multirow[t]{2}{*}{ ICAM1 } & Sense & GGTGTATGAACTGAGCAATGTG & \multirow[t]{2}{*}{ Capasso et al. (2012) } \\
\hline & Anti-sense & TGGCAGCGTAGGGTAAGG & \\
\hline \multirow[t]{2}{*}{ TNF } & Sense & TCTCGAACCCCGAGTGACAA & \multirow[t]{2}{*}{ Bahrami et al. (2011) } \\
\hline & Anti-sense & TATCTCTCAGCTCCACGCCA & \\
\hline \multirow[t]{2}{*}{$\beta_{2}$-Microglobulin $\left(\beta_{2} \mathrm{M}\right)$} & Sense & AGGCTATCCAGCGTACTCCAAAGA & \multirow[t]{2}{*}{ Nahidi et al. (2012) } \\
\hline & Anti-sense & AACGAGATCAACATCATGAACCA & \\
\hline
\end{tabular}


The low limit of detection of IL-8 and IL-6 ELISAs was 15.6 and $62.5 \mathrm{pg} / \mathrm{ml}$, respectively.

\section{Statistical analysis}

Analysis of the microarray data was undertaken using the Partek Genomic Solutions platform (Partek Inc., St Louis, MO, USA). Following import of the Affymetrix CEL files, the robust multi-array average (RMA) method (Irizarry et al. 2003) was used for background correction, quantile normalisation across all chips, $\log 2$ transformation and median polish summarisation. Differential expression was tested using one-way analysis of variance (ANOVA) with linear contrasts between (1) untreated and TNF-treated cells, (2) PF/TNF- $\alpha$ - and TNF- $\alpha$-treated cells and (3) untreated and PF/TNF- $\alpha$. Gene lists were created using a false discovery rate-adjusted $P$ value (FDR) of $5 \%$ and a fold change of at least 1.5. MetaCore ${ }^{\mathrm{TM}}$ from Thomson Reuters was used to conduct functional analysis of the differentially expressed genes including pathway analysis. Quantitative PCR and ELISA data were analysed by oneway ANOVA followed by Tukey's multiple comparison test using GraphPad Prism version 6.00 for Windows, GraphPad Software, La Jolla, CA, USA, www.graphpad. com. Data are presented as mean with standard deviation unless stated otherwise.

\section{Results}

\section{Effects of TNF- $\alpha$ and PF on cell viability}

Trypan blue dye exclusion studies were used to determine whether TNF- $\alpha(100 \mathrm{ng} / \mathrm{ml})$ or PF (1:5 dilution in media) was toxic to HT-29 cells. HT-29 cells were cultured in sixwell plates, six wells (on separate plates) were exposed to $100 \mathrm{ng} / \mathrm{ml}$ of TNF- $\alpha$ in media, six wells (on separate plates) were exposed to PF in media, and six wells (on separate plates) were cultured with media alone. TNF- $\alpha$ exposed cells displayed no significant decrease in cell viability over the 5-h experimental period [TNF-treated cells $(94.1 \pm 10.4 \%$ viability $) \quad$ vs. untreated cells (97.8 $\pm 3.2 \%$ viability); $P>0.05]$. There was also no difference in cell viability between untreated cells and those exposed to $\mathrm{PF}(95.7 \pm 5.5 \%$ viability $)$ over the experimental period $(P>0.05)$.

\section{Treatment with TNF- $\alpha$ and PF}

Next HT-29 cells were cultured in six-well culture plates until confluent. Once confluent, three wells (on separate plates) of cells were exposed to $100 \mathrm{ng} / \mathrm{ml}$ of TNF- $\alpha$ in media, three wells (on separate plates) were exposed to $100 \mathrm{ng} / \mathrm{ml}$ of TNF- $\alpha$ in 1:5 dilution of PF in media, and three wells (on separate plates) were cultured with media alone. Following $5 \mathrm{~h}$ of culture, RNA was collected and subjected to microarray analysis. Differential gene expression was undertaken to analyse cells treated with both TNF- $\alpha$ and PF compared to the cells treated only with TNF- $\alpha$. This comparison yielded 345 genes (FDR $<0.05$, fold change $>1.5$ ) (Supplementary Table 1). The ten most significant pathways represented in the set of 345 differentially expressed genes are listed in Table 2 together with the genes identified in those pathways. This highlights that NFKB1-associated pathways are the most enriched paths that show changes due to PF treatment of TNF- $\alpha$-stimulated cells.

In more detailed analysis, cells exposed to TNF- $\alpha$ had significant upregulation of genes related to the NF- $\kappa B$ pathway, as compared to untreated controls (Table 3). This effect was generally ameliorated in the cells treated with PF as well as TNF- $\alpha$. However, PF did not completely restore the cells to their untreated state. Nevertheless, PF induced a significant decrease in the key NF- $\kappa B$ pathway genes NFKB1, TNF, TNFSF10, RELB and TNIP1 and an increase in FOS (Table 2).

Table 2 Ten most significant pathways affected by polymeric formula treatment of TNF-stimulated colonic epithelium cells

\begin{tabular}{lll}
\hline Pathway & FD & Genes \\
\hline Transcription_NF-кB activation pathways & $1.5 \mathrm{E}-04$ & NFKBIE, NFKB1, RELB, BIRC2, BIRC3, TNF \\
Development_PEDF signalling & $8.5 \mathrm{E}-04$ & NFKB1, BIRC2, BIRC3, VEGFA \\
Development_VEGF signalling and activation & $2.5 \mathrm{E}-03$ & HRAS, NFKBIE, NFKB1, VEGFA, PLCG1, FOS \\
Apoptosis and survival_anti-apoptotic & $2.5 \mathrm{E}-03$ & NFKBIE, NFKB1, BIRC2, BIRC3, TNF \\
FGF signalling in pancreatic cancer & $2.5 \mathrm{E}-03$ & HRAS, NFKB1, VEGFA, FGFR2, PLCG1 1, FOS \\
Transcription_ligand-dependent activation of the ESR1/SP & $2.5 \mathrm{E}-03$ & CDC25A, CAD, VEGFA, CARM1, FOS \\
Gamma-secretase regulation of angiogenesis & $2.5 \mathrm{E}-03$ & Csk, NOTCH1, VEGFA \\
Transcription_N-CoR/SMRT complex-mediated epigenetic & $2.5 \mathrm{E}-03$ & NFKB1, RXRB, BRG1, THRB, RXRB, FOS \\
PDE4 regulation of cyto/chemokine expression in arthritis & $2.5 \mathrm{E}-03$ & NFKB1, PRKACA, NFKBIE, CARD8, TNF \\
Immune response_T cell receptor signalling pathway & $3.3 \mathrm{E}-03$ & HRAS, BCL10, NFKBIE, NFKB1, PLCG1, FOS \\
\hline
\end{tabular}


Table 3 Comparison of NFKB1-related genes with treatments

\begin{tabular}{|c|c|c|c|c|c|c|c|}
\hline \multirow[t]{2}{*}{ Gene } & \multirow[t]{2}{*}{ Affymetrix probe ID } & \multicolumn{2}{|c|}{ TNF versus untreated } & \multicolumn{2}{|c|}{ PF versus TNF } & \multicolumn{2}{|c|}{$\mathrm{PF}$ versus untreated } \\
\hline & & P_val & $\mathrm{FC}$ & P_val & $\mathrm{FC}$ & P_val & $\mathrm{FC}$ \\
\hline \multicolumn{8}{|c|}{ Activation of $N F-\kappa B$} \\
\hline NFKB1 & 11717542_a_at & $6.7 \mathrm{E}-06$ & 2.77 & $8.6 \mathrm{E}-04$ & -1.54 & $1.6 \mathrm{E}-04 *$ & 1.8 \\
\hline NFKBIA & 11757894_x_at & $2.1 \mathrm{E}-03$ & 3.7 & $2.7 \mathrm{E}-01 *$ & -1.36 & $7.6 \mathrm{E}-03 *$ & 2.71 \\
\hline NFKBIA & 11745878_x_at & $2.5 \mathrm{E}-03$ & 3.26 & $2.3 \mathrm{E}-01 *$ & -1.37 & $1.1 \mathrm{E}-02 *$ & 2.37 \\
\hline NFKBIA & 11744000_a_at & $2.6 \mathrm{E}-03$ & 3.54 & $2.4 \mathrm{E}-01 *$ & -1.4 & $1.1 \mathrm{E}-02 *$ & 2.53 \\
\hline NFKBIE & 11743007_at & $3.1 \mathrm{E}-05$ & 4.07 & $5.2 \mathrm{E}-02 *$ & -1.36 & $1.2 \mathrm{E}-04$ & 3 \\
\hline TNF & 11721577_at & $1.1 \mathrm{E}-05$ & 4.77 & $1.0 \mathrm{E}-03$ & -2.01 & $3.3 \mathrm{E}-04$ & 2.37 \\
\hline TNFRSF10B & 11719681_a_at & $9.1 \mathrm{E}-08$ & 2.72 & $4.9 \mathrm{E}-01 *$ & -1.02 & $1.1 \mathrm{E}-07$ & 2.65 \\
\hline TNFRSF10B & 11753075_a_at & $1.7 \mathrm{E}-06$ & 1.92 & $9.4 \mathrm{E}-02 *$ & 1.07 & $9.2 \mathrm{E}-07$ & 2.06 \\
\hline \multicolumn{8}{|c|}{ Positive regulation of IkB kinase/NF- $\kappa B$ cascade } \\
\hline IKBKE & 11720956_a_at & $4.6 \mathrm{E}-05$ & 2.29 & $3.1 \mathrm{E}-03 *$ & -1.46 & $1.3 \mathrm{E}-03 *$ & 1.57 \\
\hline IKBKE & 11720957_a_at & $4.1 \mathrm{E}-06$ & 2.48 & $8.1 \mathrm{E}-05$ & -1.72 & $7.0 \mathrm{E}-04 *$ & 1.44 \\
\hline TNFSF10 & 11743730_at & $1.6 \mathrm{E}-07$ & 3.29 & $1.3 \mathrm{E}-05$ & -1.76 & $7.4 \mathrm{E}-06^{*}$ & 1.87 \\
\hline TNFSF10 & 11747952_x_at & $7.8 \mathrm{E}-10$ & 3.71 & $8.4 \mathrm{E}-08$ & -1.82 & $3.0 \mathrm{E}-08$ & 2.04 \\
\hline TNFAIP3 & 11718940_a_at & $2.5 \mathrm{E}-05$ & 3.82 & $3.5 \mathrm{E}-03 *$ & -1.71 & $4.5 \mathrm{E}-04$ & 2.23 \\
\hline TNFAIP3 & 11718939_s_at & $3.8 \mathrm{E}-05$ & 7.8 & $2.0 \mathrm{E}-02 *$ & -1.82 & $2.7 \mathrm{E}-04$ & 4.27 \\
\hline TRAF2 & 11754185_a_at & $1.5 \mathrm{E}-05$ & 1.74 & $1.3 \mathrm{E}-04$ & -1.46 & $7.5 \mathrm{E}-03 *$ & 1.19 \\
\hline \multicolumn{8}{|c|}{ NF- $\kappa$ B-responsive genes } \\
\hline ICAM1 & 11747499_a_at & $8.3 \mathrm{E}-04$ & 2.13 & $4.7 \mathrm{E}-02 *$ & -1.36 & $1.0 \mathrm{E}-02 *$ & 1.57 \\
\hline ICAM1 & 11732999_a_at & $2.6 \mathrm{E}-05$ & 4.15 & $6.9 \mathrm{E}-03 *$ & -1.65 & $3.0 \mathrm{E}-04$ & 2.52 \\
\hline ICAM1 & 11733000_at & $9.4 \mathrm{E}-05$ & 4.72 & $3.4 \mathrm{E}-03 *$ & -2.2 & $4.0 \mathrm{E}-03 *$ & 2.14 \\
\hline IL-8 & 11754026_a_at & $9.3 \mathrm{E}-05$ & 37.31 & $4.0 \mathrm{E}-01 *$ & -1.43 & $1.7 \mathrm{E}-04$ & 26.15 \\
\hline IL-8 & 11763226_x_at & $1.3 \mathrm{E}-04$ & 30.75 & $3.9 \mathrm{E}-01 *$ & -1.44 & $2.4 \mathrm{E}-04$ & 21.31 \\
\hline IL-8 & 11718841_s_at & $5.9 \mathrm{E}-07$ & 40.96 & $9.4 \mathrm{E}-02 *$ & -1.4 & $1.0 \mathrm{E}-06$ & 29.21 \\
\hline \multicolumn{8}{|l|}{ Other factors } \\
\hline FOS & 11749291_a_at & $3.0 \mathrm{E}-04$ & -2.83 & $1.2 \mathrm{E}-03$ & 2.23 & $1.4 \mathrm{E}-01 *$ & -1.27 \\
\hline FOS & 11734659_a_at & $1.4 \mathrm{E}-03$ & -2.34 & $4.2 \mathrm{E}-03 *$ & 1.98 & $3.1 \mathrm{E}-01 *$ & -1.18 \\
\hline FOS & 11749852_s_at & $9.5 \mathrm{E}-04$ & -2.35 & $4.2 \mathrm{E}-03 *$ & 1.89 & $1.8 \mathrm{E}-01 *$ & -1.24 \\
\hline RELB & 11722141_at & $1.3 \mathrm{E}-06$ & 4.23 & $1.6 \mathrm{E}-03$ & -1.51 & $9.6 \mathrm{E}-06$ & 2.8 \\
\hline IL-1A & 11725198_at & $7.1 \mathrm{E}-05$ & 1.92 & $3.3 \mathrm{E}-02 *$ & -1.2 & $4.6 \mathrm{E}-04 *$ & 1.59 \\
\hline LTB & 11739658_a_at & $6.6 \mathrm{E}-05$ & 1.99 & $1.6 \mathrm{E}-03^{*}$ & -1.47 & $4.8 \mathrm{E}-03 *$ & 1.36 \\
\hline LTB & 11739657_a_at & $9.1 \mathrm{E}-05$ & 6.8 & $3.4 \mathrm{E}-03 *$ & -2.63 & $3.8 \mathrm{E}-03 *$ & 2.58 \\
\hline NFAT5 & 11738447_a_at & $8.5 \mathrm{E}-04$ & -2.07 & $1.0 \mathrm{E}-02 *$ & 1.55 & $5.1 \mathrm{E}-02 *$ & -1.33 \\
\hline NFAT5 & 11717466_a_at & $9.2 \mathrm{E}-03$ & -3.62 & $1.0 \mathrm{E}-01 *$ & 1.93 & $1.2 \mathrm{E}-01 *$ & -1.87 \\
\hline TNIP1 & 11750133_x_at & $1.0 \mathrm{E}-03$ & 1.78 & $5.1 \mathrm{E}-03 *$ & -1.52 & $1.5 \mathrm{E}-01 *$ & 1.17 \\
\hline TNIP1 & 11715898_a_at & $2.9 \mathrm{E}-04$ & 1.86 & $1.7 \mathrm{E}-03$ & -1.56 & $7.8 \mathrm{E}-02 *$ & 1.19 \\
\hline TNIP1 & 11744745_a_at & $3.8 \mathrm{E}-03$ & 1.58 & $8.1 \mathrm{E}-03^{*}$ & -1.48 & $5.2 \mathrm{E}-01 *$ & 1.07 \\
\hline TNIP1 & 11744746_x_at & $3.6 \mathrm{E}-03$ & 1.54 & $2.8 \mathrm{E}-03^{*}$ & -1.57 & $8.2 \mathrm{E}-01 *$ & -1.02 \\
\hline ROCK1 & 11739450_x_at & $6.7 \mathrm{E}-05$ & -1.94 & $1.7 \mathrm{E}-02 *$ & 1.25 & $6.3 \mathrm{E}-04 *$ & -1.55 \\
\hline
\end{tabular}

* $P$ values which are not statistically significant at an FDR $<0.05$

\section{Confirmation of microarray findings by RT-PCR}

To confirm microarray findings, the extracted RNA was also subjected to quantitative RT-PCR. Four dysregulated genes were selected for RT-PCR validation. In good accordance with microarray data, all four genes showed significant upregulation with TNF- $\alpha$ (Fig. 1). Only TNF showed significant downregulation with PF treatment (Fig. 1). 


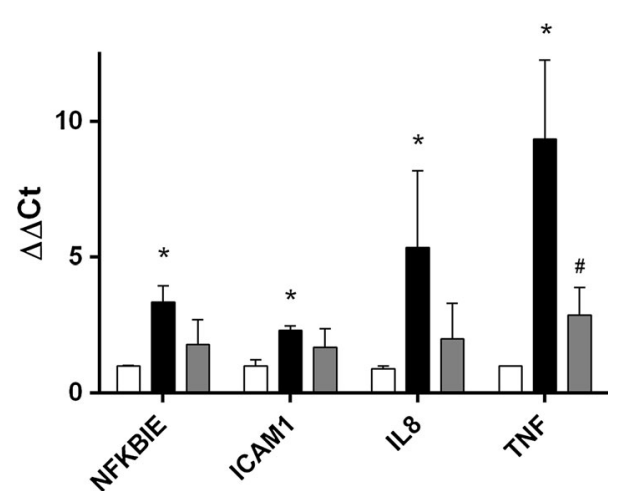

Fig. 1 Expression levels of four genes involved in the NF- $\kappa B$ pathway. Confluent HT-29 cells were cultured for $5 \mathrm{~h}$ in media alone (white), TNF- $\alpha$ in media (black) or TNF- $\alpha$ in media with PF (grey) using three replicate samples for each treatment. Following culture RNA was extracted, and four of the dysregulated genes were selected and were quantified by RT-PCR. RT-PCR gene expression was normalised to housekeeping gene $\beta_{2}$-microglobulin. In good accordance with the microarray data, all genes became significantly overexpressed following TNF- $\alpha$ treatment (black) [vs. untreated cells (white) $* P<0.05$ for all comparisons]. In further accordance with the microarray data, only expression of TNF was significantly downregulated by PF treatment ( grey) (vs. TNF- $\alpha$ treated; ${ }^{\#} P<0.05$ ). $P F$ polymeric formula: genes-ICAM1 intercellular adhesion molecule $1, I L-8$ interleukin-8, NFKBIE NF- $\mathrm{BB}$ light polypeptide gene enhancer in B cells inhibitor, $\alpha, T N F$ tumour necrosis factor. Data presented as mean with SD

\section{Elevated cytokine levels were reduced following administration of $\mathbf{P F}$}

As described in previous studies, untreated epithelial cells express only low levels of cytokines including IL-8 (Ihenetu et al. 2003; Nahidi et al. 2012), which can be elevated in a time-dependent manner upon stimulation (Ihenetu et al. 2003; Nahidi et al. 2012). Consistent with these observations, IL-8 levels were significantly elevated by TNF- $\alpha$ stimulation (vs. untreated cells $P<0.05$; Fig. 2a). Further, cells incubated with TNF- $\alpha+$ PF had reduced IL- 8 level (vs. TNF- $\alpha$-treated cells; $P<0.05$ ), although levels were elevated compared to untreated controls. IL-6 gene expression, although not reaching significant differential expression based on the microarray analysis, was investigated by measurement of IL-6 protein levels in the supernatant. Significantly $(P<0.05)$ elevated IL-6 levels were observed in the TNF- $\alpha$-stimulated cells, which were reduced/in TNF- $\alpha+$ PF cells (Fig. 2b). Supernatant IL-6 levels were not significantly different in TNF- $\alpha+$ PF cells and untreated cells $(P>0.05$; Fig. $2 b)$.

\section{Discussion}

Although the efficacy of EEN in the management of CD is well established by clinical experiences and reinforced by clinical trials, the main pathway(s) by which EEN alters
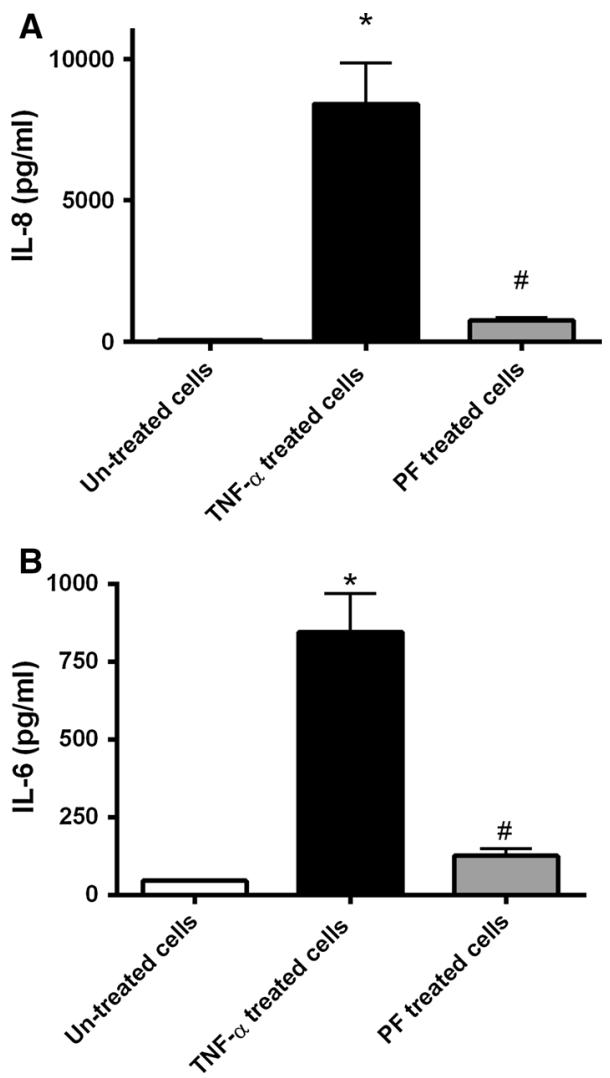

Fig. 2 IL-8 and IL-6 protein levels in cell culture supernatants. Confluent HT-29 cells were incubated with media alone or media with $100 \mathrm{ng} / \mathrm{ml}$ of TNF- $\alpha$ in the presence or absence of PF for $5 \mathrm{~h}$ with supernatants collected following incubation. Experiments were performed using three replicate samples for each treatment on two independent occasions. IL-8 (a) and IL-6 (b) protein levels were measured in the supernatants by ELISA. After TNF- $\alpha$ exposure, IL- 8 and IL-6 levels were significantly elevated (vs. untreated cells; $* P<0.05$ ). However, PF had anti-inflammatory effects on HT-29 in response to TNF- $\alpha$. The PF-treated cells had IL- 8 and IL- 6 levels below the TNF- $\alpha$-treated cells $\left({ }^{\#} P<0.05\right)$. Data presented as mean with SD

intestinal inflammatory processes is still unknown. As previously reported, the resolution of gut barrier function in the presence of PF is likely to enhance resolution of the inflammatory process in the mucosa (de Jong et al. 2007; Nahidi et al. 2012, 2013). Although the precise mode of this action is still unclear, models used in previous studies eliminated the variable of PF altering the intestinal bacteria. Therefore, there is evidence of PF directly altering inflammatory events within epithelial cells (de Jong et al. 2007). The current study indicated that PF may directly alter inflammatory events in the epithelium through modulation of NF- $\mathrm{KB}$ activation.

One of the major functions of the intestinal epithelium, lying at the interface between the gastrointestinal-associated lymphoid tissues and the intestinal microbiome, is to provide a highly effective physical barrier to control 
passage of ions, nutrients and water across the mucosa (Forster 2008). In addition to this barrier function, intestinal epithelial cells can launch an immune response to pathogenic intestinal organisms (Cario and Podolsky 2000). Intestinal epithelial cells are also able to effectively modulate underlying immune cells including $\mathrm{T}$ and $\mathrm{B}$ lymphocytes (Salim and Soderholm 2011; Yu et al. 2004). Therefore, the ability to maintain the balance between absorption of key nutrients, preventing invasion of pathogenic organisms and also regulation of immune cells forms the backbone of the intestinal mucosal barrier.

A number of pathways control the clearance of pathogens and intracellular components in the intestine including the NF- $\kappa$ B pathway (Abraham and Medzhitov 2011). NF$\kappa \mathrm{B}$ is a family of transcription factors that play a major role in the activation of genes involved in cell growth, tissue differentiation as well as immune- and acute-phase responses (Gupta et al. 2010; Schottelius and Baldwin 1999). In most cells, NF- $\kappa \mathrm{B}$ complexes are inactive, residing mainly in the cytoplasm (Oeckinghaus and Ghosh 2009). However, upon activation by a diverse range of stimuli including bacterial endotoxin, cytokines and lesioninduced oxidative stress (Oeckinghaus and Ghosh 2009), the signalling pathway enhances transcription and production of chemokines and cytokines including IL-8, IL-1 $\beta$ and TNF- $\alpha$ (Oeckinghaus and Ghosh 2009; Schottelius and Baldwin 1999). Therefore, NF- $\kappa \mathrm{B}$, and dysregulation of this pathway, has a critical role in the pathophysiology of chronic inflammatory diseases including IBD (Barnes and Karin 1997; Nahidi et al. 2012, 2013). In IBD, overactivation of the $\mathrm{NF}-\kappa \mathrm{B}$ signalling pathway, and subsequent overexpression of cytokines associated with this pathway, amplifies the inflammatory cascade resulting in tissue injury (Kruidenier and Verspaget 2002). The results of the present study also show that stimulation of epithelial cells with $\mathrm{TNF}-\alpha$ disturbs the NF- $\kappa \mathrm{B}$ signalling pathway with upregulation of the inflammatory inducers IL-8, IL-1 and TNF- $\alpha$. Owing to the role of NF- $\kappa \mathrm{B}$ in controlling multiple genes involved in inflammation and IBD, the NF- $\kappa \mathrm{B}$ signalling pathway is a key target for therapy (Gupta et al. 2010; Schottelius and Baldwin 1999).

Anti-inflammatory agents commonly used for IBD treatment include glucocorticoids and immunosuppressants (Gupta et al. 2010; Schottelius and Baldwin 1999). These agents target the NF- $\kappa \mathrm{B}$ pathway albeit by different distinct mechanisms, for example, precluding $N F-\kappa B$ translocation to the nucleus, interfering with $N F-\kappa B$ DNA-binding, binding heat-shock proteins, blocking the expression of intercellular adhesion molecule 1 (ICAM-1) and inhibiting protein phosphatase 3 (PPP3Cs) activity (Gupta et al. 2010; Meyer et al. 1997; Schottelius and Baldwin 1999; Tepper et al. 1995; Wechsler et al. 1994). An alternative approach to management of IBD, particularly $\mathrm{CD}$, is EEN. EEN is effective in reducing mucosal cytokine levels, resolving mucosal histological changes and pro-inflammatory-induced gut barrier dysfunction along with reduction in bacterial load (de Jong et al. 2007; Leach et al. 2008; Meister et al. 2002; Nahidi et al. 2012, 2013). The precise mechanism by which EEN suppresses inflammation is unknown; however, it has previously been hypothesised that EEN's therapeutic activity can be attributed to gut rest and/or modulation of gut microbiota. Previously we have shown that PF has direct anti-inflammatory activity on cultured epithelial cells and that this activity is not a result of blocking TNF- $\alpha$ binding (de Jong et al. 2007). As both elemental and PF have similar efficacy in IBD (Ludvigsson et al. 2004), it is unlikely that gut rest plays a significant therapeutic role in EEN. Therefore, we have previously hypothesised (Nahidi et al. 2014) that the activity of EEN may be a combination of restoring gut barrier function (Nahidi et al. 2013), altering gut bacteria (Leach et al. 2008) and direct anti-inflammatory activity.

The aim of the current study was to further investigate the direct anti-inflammatory activity of PF. Consistent with our previous findings, the results of the current study indicated that PF significantly reduced the inflammatory responses in TNF- $\alpha$-stimulated epithelial cells. Further, the activity of PF appears to be through direct modulation of the NF- $\kappa$ B signalling pathway with limited activity evident on additional pathways. One explanation is that PF alters the osmolality and $\mathrm{pH}$ which suppresses the inflammatory response. However, we propose that this is unlikely as PF has similar osmolality and $\mathrm{pH}$ to culture medium and any changes in osmolality and $\mathrm{pH}$ with the addition of $\mathrm{PF}$ in the in vitro model are minimal. These findings indicate that further targeted investigations to determine precisely how $\mathrm{PF}$ can modulate NF- $\mathrm{BB}$ signalling and therefore suppress inflammation are warranted.

A limitation of this study was that complete PF was added to immortalised colonic epithelial cells. It is unlikely that unaltered PF would reach the colon in situ. However, it is plausible that the epithelium in the small bowel may be exposed to PF at similar dilutions used in the current study. Therefore, it is the small bowel where the direct anti-inflammatory activity of PF is likely to have a major effect. Unfortunately, there is no widely accepted cell line that replicates small bowel epithelial cells, and the only wellaccepted model to investigate the intestinal epithelium is colonic epithelial cells. Previous studies delineating EEN activity in disease location-stratified paediatric IBD patients indicate that EEN has greater activity in ileal and ileocolonic disease and less activity in colonic disease (Afzal et al. 2005). It is intriguing to speculate that the activity of PF described in the current study may be replicated in the small bowel epithelium of EEN-treated IBD patients, although further investigations are needed to 
establish whether this activity is replicated in situ. Nevertheless, these findings further reveal a hidden activity of $\mathrm{PF}$, and additional investigations are now required to establish whether this activity contributes to the therapeutic activity of EEN and whether development of these properties is an avenue for novel therapies for IBD.

In summary, the current work has ascertained that PF has a spectrum of activity that abated NF- $\mathrm{KB}$ activation and altered inflammatory events in cultured intestinal epithelial cells. These findings will allow for further targeted investigations of the mechanisms by which PF induces disease remission in IBD, and may provide a pathway to improve and expand nutritional therapy.

Acknowledgments Laboratory investigations were performed in the Westfield Research Laboratories. Osmolite supplied by Abbott Nutrition Australia.

\section{Compliance with Ethical Standards}

Conflict of interest Lily Nahidi, Susan Corley, Marc Wilkins, Jerry Wei, Moftah Alhagamhmad, Andrew Day, Daniel Lemberg and Steven Leach declare that they have no conflicts of interest.

Human and animal rights statement This article does not contain any studies with human or animal subjects performed by any of the authors.

Funding This work was supported by the National Health and Medical Research Council, Australia (NHMRC, Grant No. 510230), by the Australian Federal Government EIF Super Science Scheme and the New South Wales State Government Science Leveraging Fund.

\section{References}

Abraham C, Medzhitov R (2011) Interactions between the host innate immune system and microbes in inflammatory bowel disease. Gastroenterology 140:1729-1737. doi:10.1053/j.gastro.2011.02. 012

Afzal NA et al (2005) Colonic Crohn's disease in children does not respond well to treatment with enteral nutrition if the ileum is not involved. Dig Dis Sci 50:1471-1475

Bahrami B, Macfarlane S, Macfarlane GT (2011) Induction of cytokine formation by human intestinal bacteria in gut epithelial cell lines. J Appl Microbiol 110:353-363. doi:10.1111/j.13652672.2010.04889.x

Ballinger AB, Savage MO, Sanderson IR (2003) Delayed puberty associated with inflammatory bowel disease. Pediatr Res 53:205-210

Barnes PJ, Karin M (1997) Nuclear factor-kappaB: a pivotal transcription factor in chronic inflammatory diseases. N Engl J Med 336:1066-1071

Benchimol EI, Fortinsky KJ, Gozdyra P, Van den Heuvel M, Van Limbergen J, Griffiths AM (2011) Epidemiology of pediatric inflammatory bowel disease: a systematic review of international trends. Inflamm Bowel Dis 17:423-439

Boonkaewwan C, Ao M, Toskulkao C, Rao MC (2008) Specific immunomodulatory and secretory activities of stevioside and steviol in intestinal cells. J Agric Food Chem 56:3777-3784. doi:10.1021/jf072681o
Capasso R et al (2012) Homocysteinylated albumin promotes increased monocyte-endothelial cell adhesion and up-regulation of MCP1, Hsp60 and ADAM17. PLoS One 7:e31388. doi:10. 1371/journal.pone.0031388

Cario E, Podolsky DK (2000) Differential alteration in intestinal epithelial cell expression of toll-like receptor 3 (TLR3) and TLR4 in inflammatory bowel disease. Infect Immun 68:7010-7017

Day AS, Burgess L (2013) Exclusive enteral nutrition and induction of remission of active Crohn's disease in children. Expert Rev 9:375-383. doi:10.1586/eci.13.12

Day AS, Whitten KE, de Jong NSH (2006) Nutrition and nutritional management of Crohn's disease in children and adolescents. Curr Nutr Food Sci 2:3-14

Day AS, Whitten KE, Sidler M, Lemberg DA (2008) Systematic review: nutritional therapy in paediatric Crohn's disease. Aliment Pharmacol Ther 27:293-307

de Jong NSH, Leach ST, Day AS (2007) Polymeric formula has direct anti-inflammatory effects on enterocytes in an in vitro model of intestinal inflammation. Dig Dis Sci 52:2029-2036

Fell JM et al (2000) Mucosal healing and a fall in mucosal proinflammatory cytokine mRNA induced by a specific oral polymeric diet in paediatric Crohn's disease. Aliment Pharmacol Ther 14:281-289

Forster C (2008) Tight junctions and the modulation of barrier function in disease. Histochem Cell Biol 130:55-70

Griffiths AM, Buller HB (2000) Inflammatory bowel diseases. In: Walker WA, Hamilton JR, Watkins JB, Durie PR, Walker-Smith JA (eds) Pediatric gastrointestinal disease, chap 641, 3rd edn. BC Decker, Hamilton, pp 613-652

Gupta SC, Sundaram C, Reuter S, Aggarwal BB (2010) Inhibiting NF-kappaB activation by small molecules as a therapeutic strategy. Biochim Biophys Acta 1799:775-787

Ihenetu K, Molleman A, Parsons ME, Whelan CJ (2003) Inhibition of interleukin- 8 release in the human colonic epithelial cell line HT-29 by cannabinoids. Eur J Pharmacol 458:207-215

Irizarry RA, Hobbs B, Collin F, Beazer-Barclay YD, Antonellis KJ, Scherf U, Speed TP (2003) Exploration, normalization, and summaries of high density oligonucleotide array probe level data. Biostatistics 4:249-264

Kanof ME, Lake AM, Bayless TM (1988) Decreased height velocity in children and adolescents before the diagnosis of Crohn's disease. Gastroenterology 95:1523-1527

Kruidenier L, Verspaget HW (2002) Review article: oxidative stress as a pathogenic factor in inflammatory bowel disease-radicals or ridiculous? Aliment Pharmacol Ther 16:1997-2015

Leach ST, Mitchell HM, Eng WR, Zhang L, Day AS (2008) Sustained modulation of intestinal bacteria by exclusive enteral nutrition used to treat children with Crohn's disease. Aliment Pharmacol Ther 28:724-733

Ludvigsson JF, Krantz M, Bodin L, Stenhammar L, Lindquist B (2004) Elemental versus polymeric enteral nutrition in paediatric Crohn's disease: a multicentre randomized controlled trial. Acta Paediatr 93:327-335

Meister D, Bode J, Shand A, Ghosh S (2002) Anti-inflammatory effects of enteral diet components on Crohn's disease-affected tissues in vitro. Dig Liver Dis 34:430-438

Meyer S, Kohler NG, Joly A (1997) Cyclosporine A is an uncompetitive inhibitor of proteasome activity and prevents NF-kappaB activation. FEBS Lett 413:354-358

Nahidi L, Day AS, Lemberg DA, Leach ST (2012) Differential effects of nutritional and non-nutritional therapies on intestinal barrier function in an in vitro model. J Gastroenterol 47:107-117

Nahidi L et al (2013) Inflammatory bowel disease therapies and gut function in a colitis mouse model. Biomed Res Int 2013:909613. doi: $10.1155 / 2013 / 909613$ 
Nahidi L, Day AS, Lemberg DA, Leach ST (2014) Paediatric inflammatory bowel disease: a mechanistic approach to investigate exclusive enteral nutrition treatment. Scientifica (Cairo) 2014:423817. doi:10.1155/2014/423817

Oeckinghaus A, Ghosh S (2009) The NF-kappaB family of transcription factors and its regulation. Cold Spring Harbor Perspect Biol 1:a000034. doi:10.1101/cshperspect.a000034

Otley AR, Russell RK, Day AS (2010) Nutritional therapy for the treatment of pediatric Crohn's disease. Expert Rev 6:667-676. doi:10.1586/eci.10.37

Otsuka H, Dolovich J, Richardson M, Bienenstock J, Denburg JA (1987) Metachromatic cell progenitors and specific growth and differentiation factors in human nasal mucosa and polyps. Am Rev Respir Dis 136:710-717

Robinson RJ, Al-Azzawi F, Iqbal SJ, Kryswcki T, Almond L, Abrams K, Mayberry JF (1998) Osteoporosis and determinants of bone density in patients with Crohn's disease. Dig Dis Sci 43:2500-2506

Salim SY, Soderholm JD (2011) Importance of disrupted intestinal barrier in inflammatory bowel diseases. Inflamm Bowel Dis 17:362-381. doi:10.1002/ibd.21403
Schottelius AJ, Baldwin AS Jr (1999) A role for transcription factor NFkappa B in intestinal inflammation. Int J Colorectal Dis 14:18-28

Tepper MA, Nadler SG, Esselstyn JM, Sterbenz KG (1995) Deoxyspergualin inhibits kappa light chain expression in 70Z/3 pre-B cells by blocking lipopolysaccharide-induced NF-kappa B activation. J Immunol 155:2427-2436

Thomas AG, Taylor F, Miller V (1993) Dietary intake and nutritional treatment in childhood Crohn's disease. J Pediatr Gastroenterol Nutr 17:75-81

Watanabe K et al (2013) Sevoflurane suppresses tumour necrosis factor-alpha-induced inflammatory responses in small airway epithelial cells after anoxia/reoxygenation. $\mathrm{Br} \mathrm{J}$ Anaesth 110:637-645. doi:10.1093/bja/aes469

Wechsler AS, Gordon MC, Dendorfer U, LeClair KP (1994) Induction of IL-8 expression in $\mathrm{T}$ cells uses the CD28 costimulatory pathway. J Immunol 153:2515-2523

Yu Y, Sitaraman S, Gewirtz AT (2004) Intestinal epithelial cell regulation of mucosal inflammation. Immunol Res 29:55-68

Zhang N et al (2009) The antiangiogenic effects of tyroservatide on animal models of hepatocellular carcinoma. J Cancer Res Clin Oncol 135:1447-1453. doi:10.1007/s00432-009-0589-1 